\title{
Proposed New Constitution for Belgian Telegraph and Telephone Administration.
}

THE Minister responsible for the Belgian telegraph 1 and telephone services, which at the present time are conducted by a self-contained department of the Ministry of Railways, Marine, Posts, Telegraphs, Telephones, and Aeronautics, has presented a report to his government indicating some of the difficulties which are experienced in providing adequately for the public needs in relation to these two services under the existing organisation of the department. Particularly, it has been found that the provisions of a law of 1846 dealing with the State finances are not sufficiently elastic to permit of the existing telegraph and telephone systems being maintained and developed with the degree of efficiency necessary in an undertaking of a commercial and industrial character, and consequently a new constitution is required for the conduct of these services. At the same time it is considered essential that the public telegraph and telephone systems in Belgium should continue to remain under State control.

The Belgian Government has been impressed with the arguments advanced in the report above mentioned in favour of the proposed reorganisation, and recognises the need, not only from the point of view of the economic life of the country, but also from that connected with the restoration of the nation's financial stability, for immediate action being taken to alter the present arrangements for carrying on these two important services. Accordingly a Bill, which the Government states is of an urgent nature, has been introduced by it in the Belgian Senate providing for the creation of a new "Telegraph and Telephone Administration."

It is the intention of the Belgian Government that the proposed Telegraph and Telephone Administration shall be endowed with the legal status of a corporation, which will have imposed upon it the duty of conducting the public telegraph and telephone services, including wireless, in the national interest, on lines similar to those in vogue in up-to-date industrial and commercial undertakings. The framers of the Bill have sought to remove, so far as it is possible to do so, the risk of a conflict between the State and the proposed Telegraph and Telephone Administration.

The Bill provides that the management of the Telegraph and Telephone Administration shall be entrusted to a board or commission, of which the Minister in charge of the telegraph and telephone services, or his deputy, is to be the president. There are to be eighteen other members, and it is expressly laid down that three of them shall be selected by reason of their special knowledge of the technical side of the problems connected with these services. Of the remaining members, eleven are to be chosen from lists prepared by certain Chambers of Commerce and other important institutions, whilst one member is to be nominated by the Finance Minister, and three others, who must be on the staff of the Telegraph and Telephone Administration, are to be nominated by the president of the commission. The existing telegraph and telephone networks will be transferred to the commission, which will make payments to the Belgian State Treasury in accordance with the provisions of the proposed law, which deals fully with the method in which the public telegraph and telephone undertakings are to be financed. The text of the Bill, in extenso, has been published in the issue of L'Echo de la Bourse (of Brussels) for Oct. 22, 1928.

\section{The Faraday Society.}

\section{Celebration of the Twenty-Frfth Anniversary.}

$\mathrm{A}^{\mathrm{N}}$ event of considerable importance and interest in the world of science is the twenty-fifth anniversary of the foundation of the Faraday Society. This was celebrated on Friday, Nov. 9, first by a luncheon which was attended by representatives of scientific institutions from the leading countries of the world, and then by the delivery of the first Spiers Memorial lecture by Sir Oliver Lodge at the Royal Institution. Prof. T. M. Lowry, president of the Faraday Society, presided at the luncheon, at which were representatives of the Union Internationale de Chimie Pure et Appliquée, the Bunsen Gesellschaft, the American Chemical Society, the National Research Council of Italy, the Institute of Physics, the Institution of Electrical Engineers, the Physical Society, and others.

During the course of the speeches at the luncheon, Prof. E. C. Biilman, representing the Union Internationale de Chimie Pure et Appliquée, presented to the Faraday Society two volumes containing correspondence between Oersted and the technical societies, and also between him and Faraday. One other item of interest during the luncheon proceedings was the great compliment paid to the late Mr. F. S. Spiers for his organisation of the general discussions of the Faraday Society-which it was suggested were rendered the more valuable by the co-operation of men of science in other countries-and the suggestion of the president that there might be organised international general discussions which would take place alternately in different countries.

Sir Oliver Lodge took as his subject for the first
Spiers Memorial Lecture, "Some Debatable Problems in Physics," in which he first discussed the seat of the electromotive force in the voltaic pile. He related something of the discussions that have taken place upon this matter, and commented on the fact that they have continued throughout the nineteenth century and are continuing into the twentieth. At the same time, he rather suggested that although there have been acute differences of opinion on the matter, the advocates of the different points of view are really much of the same opinion, and some of the difficulty has been introduced by different modes of expression. Indeed, taking Poynting's diagram of energy paths, Sir Oliver suggested that this is a complete reconciliation of the views on both sides and justifies the rival views. It indicates, said Sir Oliver, that the rival views have a great deal in common, but that those who have been expressing them have not done so in the most convenient way. It is legitimate but not convenient to define potential as that in the air near the metal; if we do that we get into trouble.

In the latter part of the lecture Sir Oliver Lodge dealt with one or two matters indicating how small effects observed in the laboratory become very important as time goes on. He commented on the fact that the contact of two metals, as in the voltaic pile, led to modern electrical generation, and how closely the small observation of Becquerel on spontaneous radioactivity is related to atomic disintegration. From this he passed on to the dissipation of energy, and asked the question whether, after all, matter does turn into radiation and that that is the end of it.

No. 3081, VoL. 122] 